\title{
開口部を有するアトリウム空間の屋内温熱環境特性と 空調負荷に関する研究 \\ STUDIES ON CHARACTERISTICS OF INDOOR THERMAL ENVIRONMENT AND AIR-CONDITIONING LOAD IN ATRIUMS WITH OPENINGS
}

\author{
諏訪好 英*, 藤井修二**, 湯 浅和博***, 佐藤陽子**** \\ Yoshihide SUWA, Shuji FUJI, Kazuhiro YUASA and Yoko SATO
}

\begin{abstract}
Characteristics of indoor thermal environment and air-conditioning load in atriums with openings were studied using a simplified prediction model. Influence of draft airflow through openings was modeled using the result of CFD analysis, and the model was improved to investigate indoor thermal environment with natural ventilation.

Difference of thermal distribution and air-conditioning load were studied under several conditions, and the most effective condition for energy conservation was investigated. Finally, a periodic control method of openings was suggested. In this method, outside air will be adaptively introduced according to the outside temperature and intensity of solar irradiance. As the result of thermal load prediction through a year, it was found that this method is effective to reduce thermal load for a long priod during spring to autumn, and more than $20 \%$ of yearly air-conditioning energy will be reduced.
\end{abstract}

Keywords : atrium, indoor thermal environments, natural ventilation, air - conditioning load, simplified prediction model

アトリウム，屋内温熱環境，自然換気，空調目荷，簡易予湘モテル

1. 緒 贯

近年, 大型建築物のシンボルとして，また都市空間へのアメニティの 提供を目的として各種のアトリウムが建設されるようになった。これら アトリウム空間の多くはガラス面を多用した大空間棤造物として構成さ れており，太陽光の取り込みと視覚効果とによって利用者に屋外環境的 な開放感を与えている。しかしガラス面の割合や天井高が大きなアトリ ウム空間では一般に温度のばらつきや空調負荷が大きくなる傾向がある 1)。このためアトリウム空間の温熱環境制御には多くの課題が残されて いる。またアトリウムの多くは膨大な内部空間容積を有しており, 大容 量の空調設備およびその運転コストが必要となる。アトリウム空間の温 熱環境制御には空調消費エネルギーの削減も重要な課題となっている。

これらの問題を改善するひとつの方法として自然通風の積極的な利用 が考えられる。一般に天井高の大きな吹き抜け空間では成層的な垂直温 度分布が形成されるため，その上層部に高温の空気による熱だまりを生 じる。アトリウム空間の利用方法として上層部分を利用する場合，熱だ まりの存在は直接的な問題となるか，低層部分のみを居住域とする場合 にも上下温度差の発生は空間内の温熱環境制御に少なからぬ障害をおよ ぼす。上層部分に適当な開口を設けて自然通風を導入すると熱だまりの 除去が可能となるとともに，外部気象条件との関係を十分考虑して開口
の開開操作を行えば外気冷房的な効果が得られ, 空調消費エネルギーを 削減することも可能と考えられる。本研究では大空間の熱目荷計算手法 として用いられている温熱環境予湘モデルを応用し, 自然通風の利用に よる温熱環境制御と空調消費エネルギー削減の可能性を考察した。

\section{2. 外部気流の影響を考虑した温熱環境予測モデル \\ 2.1 既往の研究との関係}

大空間㭗造物の温熱環境予測手法についてはこれまで多くの研究が行 われており, 流体の数值解析手法 (CFD : Computational Fluid Dynamics) を応用したすの2)と，いわゆるマクロモテルを用いた現象予測 手法とが試みられている。先述したように天井高の大きなアトリウム 空間では温度成層が発達しやすく，垂直方向にのみ大きな温度差を生じ る。マクロモテルはこの特性を利用し, 空間内を垂直方向に分割して各 層の流量収支，熱量収支から屋内の垂直温度分布を計算するもので，垂 直方向に空間分割能を有する一種の熱回路網的なモデと言える。マク ロモデでは CFD のように詳細な気流, 温度の 3 次元分布を扱うこと はできないが，大空間構造物の温熱環境として重要な垂直温度分布の影 響を考虑した空調目荷の予測が可能なこと，年間しベルの長期現象予湘 が可能なことなど，簡易的な温熱環境予测手法として多くの利点を有し

\footnotetext{
* 侏大林組技術研究所数值解析研究公 工博

** 東京工業大学大学院情報理工学研究科教授. 工博

*** 東京工業大学建築学科 助手 $\cdot$ 工博

**** (侏)東京ガス商品技術開発部
}

Computational Eng. Dept., Tech. Research Inst., Obayashi Corp., Dr. Eng. Prof., Graduate School of Information and Sci. and Eng., Tokyo Inst. of Technology, Dr. Eng.

Research Assoc., Dept. of Arch. and Building Eng., Faculty of Eng., Tokyo Inst. of Technology, Dr. Eng.

Residential Energy Systems R\&D Center, Tokyo Gas Co., Ltd. 


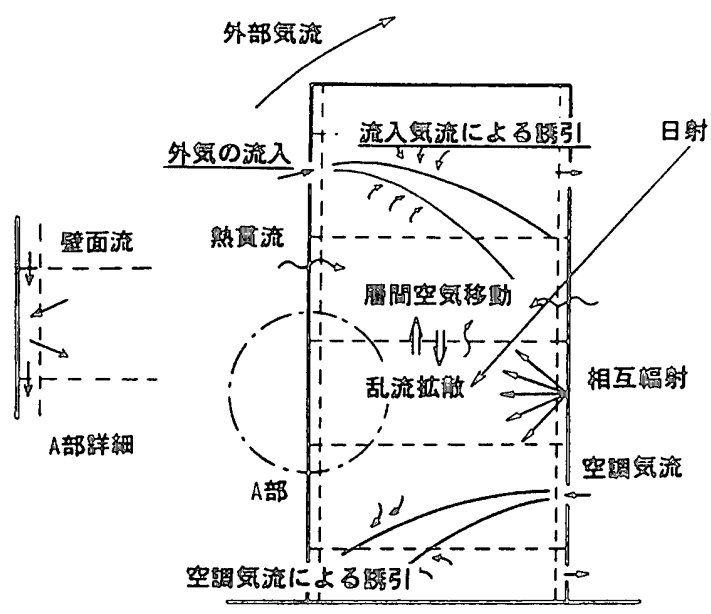

図1アトリウム内温熱環境予椡そデルの摡要

ている。

マクロモデルによる屋内上下温度分布予湘手法の研究は宮川ら3),4), 伊藤ら5) に端を発するむのと考えられるが，海外でも同時期に Gautier

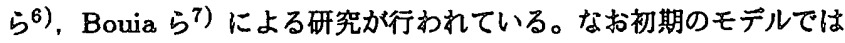
層間熱移動の割合などを経験定数として扱っていたため，対象に合わせ た定数の割り出しが必要であったが，後述するように戸河里ら ${ }^{8) \sim 10) ， ~}$ 石田ら ${ }^{11), 12)}$ 以降のモテルでは予備実験を必要としない汎用的な手法と して大系化されつつある。

また従来の手法ではいずれも屋内を独立した䦥鎖空間として扱ってお り，外部環境との空気のやりとりに伴う熱量授受を考息することは图難 であった[注1]。本研究で対象とする自然換気効果については，重力換気 の応用と外部気流による自然通風の応用とが考えられるが，前者につい ては Manzoni and Rongére ${ }^{13)}$ が, 後者については等者らがマクロモ テルへの組み込みを試み，既報 ${ }^{14}$ (以下前報と呼ぶ)において CFD と の比較により冷房時, 暖房時のアトリウム内垂直温度分布とその日変化 を定量的に予測できることを示している。本報では刻々変化する外部条 件を気象データから読み込みながら屋内温熱環境亡空調目荷の予測を行 い，その特性を竞討するため，前報で報告したモデルいくつかの改良 を試みている。

\section{2 アトリウム内温愁㻴境のそデル化の方錇}

マクロモテルでは屋内を図 1 に示すような層に分割し，層間の熱犂動 に関する平衡式から各時刻における屋内の垂直温度分布を動的に計算す る。なお図中に下線付きで示した部分が前報において自然換気勃果を考 凰するため追加されたモテルである。先述したように戸河里ら以降のモ デでは壁面流や空調気流による層間の空気移動とこれに伴う熱移動と を同時に扱う方法が用いられるようになり，外部条件の変化や屋内の分 割層の設定などに対して十分な任意性が得られるようになった。このよ うな方針に基づき現象予測した結果が実駼的に求めた熱量配分係数を比

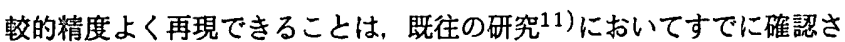
れている。前報で權築したモデは，戸河里ら以降のモテル化の方針に 従い，これに開口部から流入する外気の流れを非等温噴流モテルとして 組み込んた゚ものである。

表 1 に本モテルで用いた基磁式と各式で考舁した環境要因とをまとめ

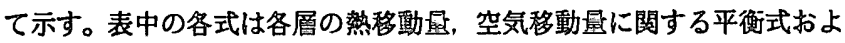
び壁体温度に関する熱平衡式をそれぞれ表している。屋内各層の空気移 動が壁面流，空調気流および開口からの外気の流入により駆動される

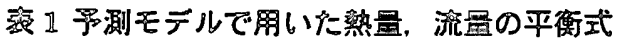

\begin{tabular}{|c|c|}
\hline 平衡式 & 想定した㻴境要因 \\
\hline 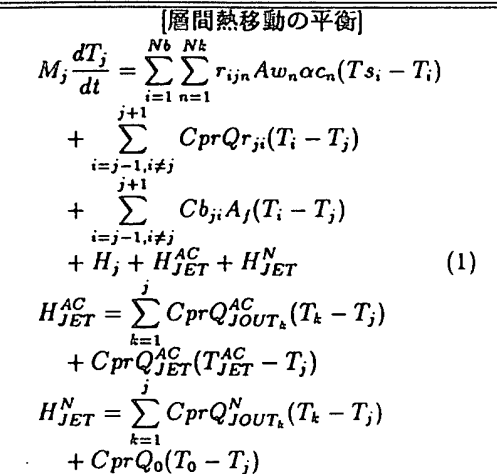 & 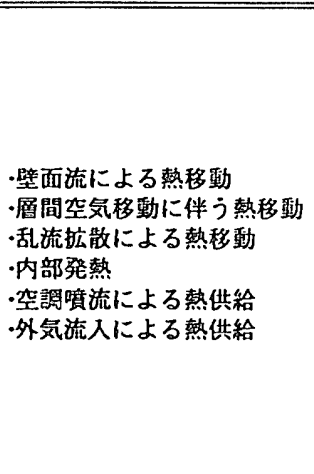 \\
\hline $\begin{array}{l}\sum_{k=1}^{N k}\left(Q w_{i n, k}-Q w_{o u t, k}\right) \\
+\sum_{i=j-1, i \neq j}^{j+1} Q r_{j i}+Q_{J E T}^{A C}+Q_{0} \\
-\left(Q_{J O U T}^{A C}+Q_{J O U T}^{N}+Q_{R E T}^{A C}+Q_{O U T}^{N}\right) \\
\quad=0\end{array}$ & 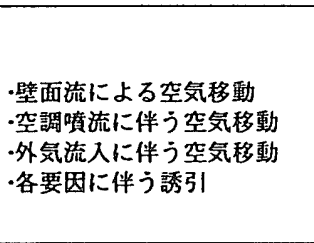 \\
\hline 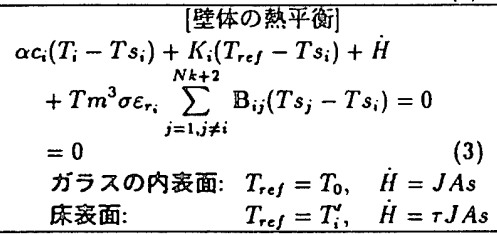 & 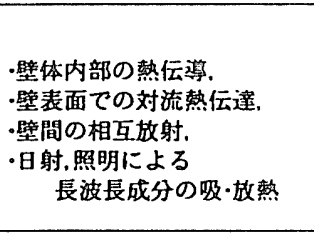 \\
\hline
\end{tabular}

のと仮定すると，これらに伴う各層間の空気移動量を(2) 式から求める ことができるまた空調吹き出し，外気流入および内部発熱により供給 される熱量と乱流拡散に伴う層間熱移動とを考虙すると，屋内各層の温 度分布か (1) 式により求められる。(1) 式，(2) 式の計算で必要となる内 壁表面温度は (3) 式から算出する。本研究ては (1) (3) 式を順次反復 計算することにより，それそれれの相互作用を含めた現象予湘を行っだ。

なお本手法では乱流による熱拡散効果を計算する際に，唯一の経験定 数として $C b$ 値を用いる。 $C b$ 值については，これを一定としても十分 現象を再現できることが既往の研究において示されており，本研究でも 戸河里らの例 ${ }^{15)}$ に従い $C b=2.326 \mathrm{~W} / \mathrm{m}^{2} k\left(2.0 \mathrm{kcal} / \mathrm{m}^{2} h\right)$ とした。ま た冬䆘には絵内ら ${ }^{16)}$ 加指摘するように上層温度が下層温度よりす低く なる逆祘現象の発生が予測されるため，このような場合についてのみ $C b=\infty$ として上下層の熱拡散を促進させる方法を採用した。以下，本 報で用いた予湘モテルに関して前報からの変更点を中心に細述する。た だし前報および参考文献においてすでに論じられている部分については 再揭となるか，モテル化の流れを把握できるようこれらについても簡単 に示すこととする。

\section{3 各程環境要因の計算方法}

日射，熱貫流や壁面流などの要因は (1) （3) 式右玏の各項として評 価される。外気の流入を除く要因のモテル化はすでに既往の研觉で検討 されており，本研究で用いた方法も基本的にはこれらを基整として權成 されている。以下，代表的な環境要因について本報で用いた計算方法を 以下に示す。

\section{[壁面流と空調気流のモデル化]}

壁面流のモデル化は基本的に戸河里らが提案した方法と同様である [注2]。着目する層と壁面との温度差から上昇流、下降流の場合分けを行 い, 着目層から各層への熱移動に関する影響係数を順次計算していく。 空調気流のモテル化にはいくつかの方法が検討されているが、ここで 
は石田らと同様の非等温噴流モデルの経験式[注3]を用いた。これにより 気流が各層界面を横切る際の誘引量計算之供給熱量の到達層判定を噴流 軌跡に沿って順次行うことが可能である。

\section{[内表面温度の計算]}

ガラス面, 床面などの内表面温度の計算には熱伝達，熟貫流および壁 体間の相互放射を考虑する。前報では相互放射の計算に形態係数法を用

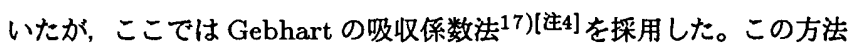
によればガラス面を含めた内表面温度は (3) 式に示したように統一的に 扱え，また日射吸収率 $A s$ の導入によりサッシ枠により遮蔽される日射 成分を吸熱成分として扱うことが可能となる ${ }^{18)}$ 。

\section{[日射受熱量の計算]}

日射受熱量の計算も基本的に前報で採用した方法[注5]と同じである。 各面における日射投影面積を透過面ことに幾何学的に計算し，各面での 入射角度と透過率を考虑して受照面積比で重み平均した値として日射受 照量を計算する。ただし本研究ではサッシの枠による日射入射量の損失 分を見込み，透過成分について損失分差し引いた值を，ガラス面での日 射吸収率について損失分割り増しした值をそれぞれ用いることとした。 2.4 開口からの流入気流のモテル化

前報では流入気流による影響についてモテル化の方針を検討した。 下前報からの変更点を中心に示し，重複する部分については考え方のみ 簡単に示すこととする。まず開口から流入する外気の影響は次の 3 つの 要素によりモテル化できるむのと考える。すなわち，

- 外気の流入流量

・開口部での外気の流入角度

・屋内に流入した後の気流の広がり角度と主流の軌跡

以下，それぞれの要因に関して本研究で用いた計算方法を示す。

[外気流入量の算出]

開口部での外気流入量は，建築物外壁表面における压力係数の分布を 用いて次式により算出する。すなわち，

$$
\sum_{i=1}^{N} Q_{0_{i}}=\frac{2 g}{\gamma} \sum_{i=1}^{N} \alpha_{i} A_{i} \frac{\left|\Delta P_{i}\right|}{\sqrt{\Delta P_{i}}}=0
$$

この方法による通風量予測の妥当性については既に前報で議論してい る。なお外壁表面における各部風圧係数は，あらかじめ CFDにより計 算して結果をテータバッファに保管し, 開口設置位置に合わせて線形補 間して用いる。

\section{[開口部における外気の流入角度]}

前報において外気の流入角度は開口の設置位置により一意に定まるも のと仮定し，開口設置高さの関数として近似する方法を用いた。本報で の現象予測には比較的長期の熱負荷計算を想定しており，各時刻におけ る風向，風速条件は大きく変化する。ここでは風向，風速条件ごとにお らかじめ集計した流入角度のテー夕を風圧係数の場合と同㥞のバッファ に保管し，各時刻の条件ことにその值を参照することとした。なお想定 した開口位置がバッファ内の定義点と一致しない場合には，風圧係数の 場合と同様に線形補間した值を使用する。

\section{[屋内流入後の外気の流れ]}

屋内流入後の流れは空調気流と同棣の非等温噴流として近似し[注6], 外気の到達層および流入気流に伴う各層界面での誘引流量を空調噴流の 場合と同様にして順次計算する。このとき非等温噴流モテルの吹き出し 角度は外気流入角度とする。

\section{5 参照用データの作成}

各時刻における外部気流状況に合わせて 2.4 節に示した 3 つの要素を 計算するためには，風圧係数，外気流入角度などの分布に関する参照用 テータが必要となる。このため，想定される外部気流の風向，風速条件 について CFD による建築物周辺気流の解析を実施し，現象予測に必要 となるテータをあらかじめテーブル化してデータバッフに保管した。

CFD による建築物周包気流解析の概要と集計したデー夕内容を表 2 および表 3 に，また解析対象とした建築物形状を図 2 にそれぞれ示す。 当然ながらここで解析対象とした建築物は, 後述する屋内環境解析の対 象建策物と同様の外部形状としている。解析領域全体の大きさは主流方 向, スパン方向に建策物一边の 4 倍, 鈶直方向に対象建築物高さの 2 倍 とし，流入境界での風速および乱流統計諸量のプロファイルの設定は文 献19)に準じた。ここでは外部気流の風向，風速条件を表 3 の条件に合 わせて変化させ, 開口のない場合について解析した結果から外壁表面で の風圧係数分布と壁面に平行な方向の風速分布[注7]を，また図 2 に併記

表 2 CFDによる気流解析に用いた手法の概要

\begin{tabular}{|c|c|c|}
\hline 基礎方程式 & \multicolumn{2}{|c|}{ Navier-Stokes 方程式 } \\
\hline 移流項の離散化 & \multicolumn{2}{|l|}{ QUICK 法 } \\
\hline アルゴリズム & \multicolumn{2}{|r|}{ (収束判定值 $=10^{-3}$ ) } \\
\hline 乱流モデル & \multicolumn{2}{|c|}{ 標準 $k$-ยモデル } \\
\hline 計算領域 & \multicolumn{2}{|c|}{$80 m(W) \times 80 m(L) \times 80 m(H)$} \\
\hline 計算格子 & \multicolumn{2}{|c|}{$\begin{array}{l}\text { 直交格子系, スタッガード変数配置 } \\
\text { 計算格子数 : } 64(W) \times 64(L) \times 55(H)\end{array}$} \\
\hline \multirow{4}{*}{ 境界条件 } & 流入境界 & $\begin{array}{c}1 / 4 \text { 乗則プロフフイル: } \\
u_{1}=x_{3}^{0.25} . \quad k=0.0025 \\
\varepsilon=\sqrt{C_{\mu}} k \partial u_{1} / \partial x_{3} . \\
C_{\mu}=0.09\end{array}$ \\
\hline & 流出境界 & 自由流出 \\
\hline & 例面，上部 & すべり壁 \\
\hline & 壁面, 地表面 & $\begin{array}{l}\text { 対数則壁関数: } \\
k=C_{\mu}^{-1 / 2} \tau_{W} / \rho, \\
\varepsilon=C_{\mu}^{3 / 4} k^{3 / 2} /\left(\kappa h_{p}\right) \\
\kappa=0.4\end{array}$ \\
\hline
\end{tabular}

表 3 作成した参照用データ

\begin{tabular}{|c|c|}
\hline テータの内容 & 設定条件 \\
\hline \begin{tabular}{l}
\multicolumn{3}{l}{ [風压係数] } \\
集計筒所: \\
各外壁面 \\
分解能 : $\quad 1 m \times 1 m$ 格子点
\end{tabular} & $0^{\circ}, 22.5^{\circ}, 45^{\circ}$ \\
\hline $\begin{array}{l}\text { [外気の流人角度] } \\
\text { 集計筒所：風上側 } 18 \text { 簓所 }\end{array}$ & $0^{\circ}, 22.5^{\circ}, 45^{\circ}$ \\
\hline $\begin{array}{l}\text { [外表面の風速] } \\
\text { 集計筒所： 各外壁面 } \\
\text { 分解能： } 1 \mathrm{~m} \times 1 \mathrm{~m} \text { 格子点 }\end{array}$ & $\begin{array}{l}\text { 風向角度 } 0^{\circ}, 22.5^{\circ}, 45^{\circ} \\
\text { 風速 } 2 \mathrm{~m} / \mathrm{s}, 4 \mathrm{~m} / \mathrm{s}, 6 \mathrm{~m} / \mathrm{s}\end{array}$ \\
\hline
\end{tabular}

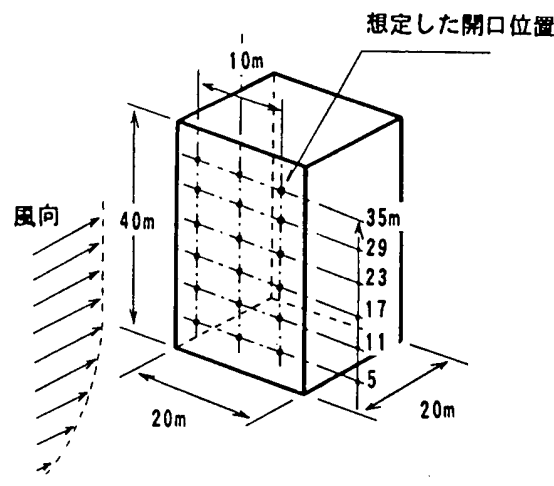

図 2 参照用データ作成のための CFD 解析対象 
した 18 箅所にそれぞれ開口を設けた場合について解析した結果から外 気流入角度を集計した。なお各時刻の外部条件として参照した気象デー 夕の分解能に合わせ風向条件は $22.5^{\circ}$ づつ変化させることとし，外壁 表面での風圧係数および壁面での風速分布については $1 \mathrm{~m} \times 1 \mathrm{~m}$ の分腾 能でテータを集計した。またマクロモテルの計算に必要となる非等温喷 流モテルの吹き出し角度は鉛直方向成分であるから, 流入気流の角度に 関しては鉛直方向成分のみを集計した。バッファに保管した参照用デー 夕は, 図 3 に風圧係数分布の例を示すように既往の研究による実験結果 20）之す定曷的によく一致している。

\section{6 空調制御のモテル化と空調負荷の評洒}

前節までの内容を 2.1 節に示した考え方に合わせて組み合わせ，屋内 温熱環境予測モテルの形にまとめた。空調時間帯における空調制御方法 に関しては CAV 制御を想定し，各時刻において次の上うに吹き出し温 度の制御を行うこととした。すなおち，

（1）最大空調容量に相当する吹き出し温度を設定し，各層の温度を計 算する。

（2）空調制御層の温度と設定温度とを比較しながら，次式により吹き 出し温度を反復的に修正する。

$$
\begin{aligned}
& T_{J E T}^{\prime}=T_{J E T}-C_{A C} \operatorname{sgn}\left[T_{j}-T_{S E T}\right]\left(T_{J E T}^{M A X}-T_{S E T}\right) \\
& C_{A C}=2^{(1-n)}
\end{aligned}
$$

また各時刻における空調目荷については，吹き出し温度が設定温度以 上の場合を暖房目荷, 設定温度以下の場合を冷房負荷とし，空調制御層 の温度をバランスさせるのに必要な供給熱量として集計することとし た。屋内の負荷が最大空調容量を越えた場合には，空調苗荷は空調機を 最大容量で運転したときの供給熱量として評価される。

\section{3. 開口部を有するアトリウム内の温熱環境に関する考察}

\section{1 对像旉案物の設定}

開発した屋内温熱環境予測モテルを用いて，外気を導入した場合のア トリウム内温熱環境および空調目荷特性を考察した。想定した対象建 筑物の概要を图 4 および表 4 に示す。ここでは基礁的な特性の把握を 目的としているため, 対象建篹物は $20 m(W) \times 20 m(L) \times 40 m(H)$ の 単純な立方体形状とし，壁面はすへて熱反射ガラスで棈成されている むのとした。ここでは屋内を 6 層に分割し，対向する 2 つの壁面には $1 m(W) \times 3 m(H)$ の単純開口をそれぞれ 5 ヶ所ずつ 1 列に配置するこ ととした。なお以下の釦討では風上側，風下側の開口設置高さを変化さ せて現象予測を行った。本論文では風上側開口を $m$ 層，風下側開口を $n$ 層に設置した場合を便宜的に $m-n$ 開口条件と呼び，以下同様の表記 を用いることとする。

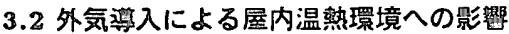

開口の設貴による影響を考察するため, 開口を設けた場合 (5-5 開口 条件)，開口のない場合の夏季におりる温熱環境の日変化を比較した。 計算に用いた気象テータおよび計算結果を图 5 にまとめて示す。空調制 御層および空調吹き出し口，レターン吸い込み口はいずれも第 1 層に設 定し，8 時から19 時まで設定温度 $26^{\circ}$ Cとして空調を行った。な訪計算 結果の再現性を確保するため，ここでは同一気象デー夕により連続 10 日間分の計算を行った。図はその最終日の結果を示している。

いずれの場合き屋内空間温度は $8 \sim 10$ 時および 16 時近傍に極大值 を，また冷房目荷は正午過ぎ最大值を示している。屋内空間温度の極 大值が 2 つのピークを示すのは気象テータの日射量と外気温度のピーク

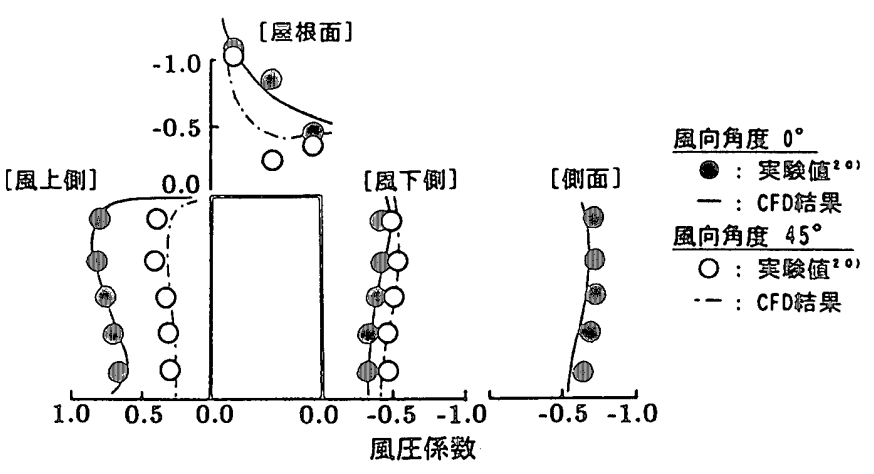

图 3バッファに保管した風圧係致分布

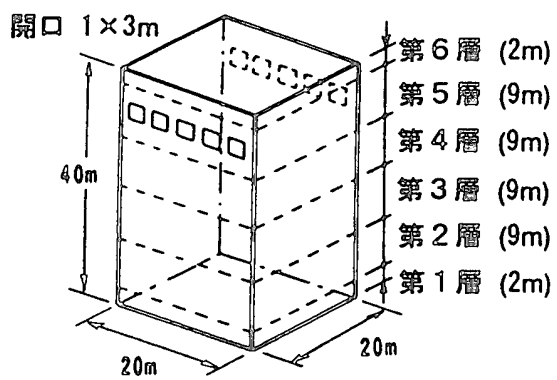

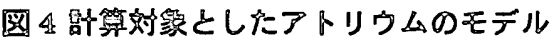

\begin{tabular}{|c|c|c|c|c|c|c|}
\hline 屋内寸法 & \multicolumn{6}{|c|}{$20 m(W) \times 20 m(L) \times 40 m(H)$} \\
\hline \multirow{9}{*}{ 樓成材㪴 } & \multicolumn{6}{|c|}{ 㑡面： 挂線反射ガラス $(6 \mathrm{~mm})$} \\
\hline & \multirow{2}{*}{ 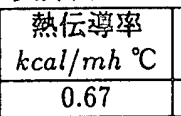 } & $\begin{array}{l}\text { 容量比熱 } \\
\mathrm{kcal} / \mathrm{m}^{3}{ }^{\circ} \mathrm{C}\end{array}$ & 透過率 & \multicolumn{2}{|c|}{ 反射率 } & 吸収率 \\
\hline & & 483.0 & 0.60 & & 30 & 0.10 \\
\hline & \multicolumn{6}{|l|}{ 床面: } \\
\hline & \multicolumn{2}{|c|}{ 權成材料 } & $\begin{array}{l}\text { 熱伝榭 } \\
\mathrm{kcal} / \mathrm{mh}\end{array}$ & & \multicolumn{2}{|c|}{ 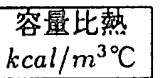 } \\
\hline & \multicolumn{2}{|c|}{ マープル $(10 \mathrm{~mm})$} & 1.35 & & \multicolumn{2}{|c|}{561.0} \\
\hline & \multicolumn{2}{|c|}{ モルタル $(20 \mathrm{~mm})$} & 1.12 & & \multicolumn{2}{|c|}{382.15} \\
\hline & \multicolumn{2}{|c|}{$\mathrm{RC}(150 \mathrm{~mm})$} & 1.20 & & \multicolumn{2}{|c|}{461.93} \\
\hline & \multicolumn{2}{|c|}{ ポリスチレン $(100 \mathrm{~mm})$} & 0.03 & & \multicolumn{2}{|c|}{7.17} \\
\hline \multirow[b]{2}{*}{ 開口部 } & \multirow{2}{*}{$\begin{array}{l}\text { 形状: } \\
\text { 寸法: } \\
\text { 設置位置: }\end{array}$} & \multicolumn{3}{|c|}{ 短形篗純開П } & & \\
\hline & & \multicolumn{2}{|c|}{$\begin{array}{l}\operatorname{lm}(W) \times 3 m(H \\
\text { 風上侧，風下゙側に }\end{array}$} & & \multicolumn{2}{|c|}{5 䈏所 } \\
\hline \multirow{6}{*}{ 空調設定 } & \multirow{5}{*}{$\begin{array}{l}\text { 空調对象: } \\
\text { 空調時間: } \\
\text { 制御方法: } \\
\text { 吹き出し口: }\end{array}$} & \multicolumn{4}{|c|}{ 第1層 (居住域)の温度 } & \\
\hline & & \multirow{2}{*}{\multicolumn{5}{|c|}{$\begin{array}{l}8 \text { 時〜 } 19 \text { 時.日曜, 休日も迅轻 } \\
\text { 冷房, 暧房とも CAV 制御 }\end{array}$}} \\
\hline & & & & & & \\
\hline & & \multicolumn{5}{|c|}{ スロット型 } \\
\hline & & \multicolumn{2}{|c|}{ 相当径 $250 \mathrm{~mm}$} & \\
\hline & $\begin{array}{l}\text { 吹き出し. } \\
\text { 吸い込み位置: }\end{array}$ & \multicolumn{2}{|c|}{ スロー定数 5.6} & & & \\
\hline
\end{tabular}

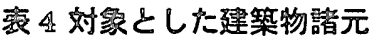

が異なること，透過吸収および熱貫流による熱移動速度が異なることな どに起因すると考えられる。計算結果から，開口を設けた場合には幄内 上下温度分布のばらつきが改善され，冷房目荷が大幅に低減できること がわかる[注8]。

3.3 開口の設罾高さによる特性の違い

開口の設置高さを变化させた場合について同様の計算を行い，その影 響を考察した。図 5 と同様の気象条件で開口設置高さを変化させて計算 した結果を図 6 に示す。図6a) は風上側，風下側開口設置高さが同じ 


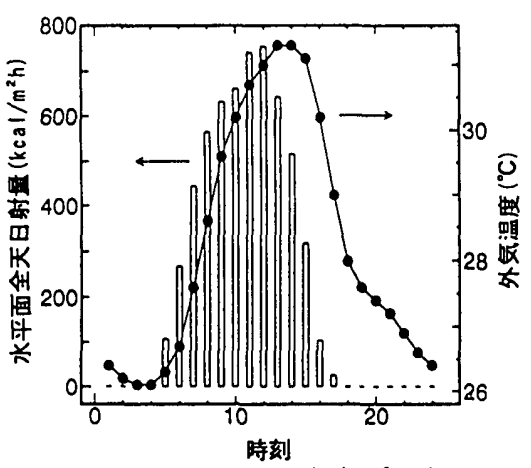

a)計算に用いた気象データ

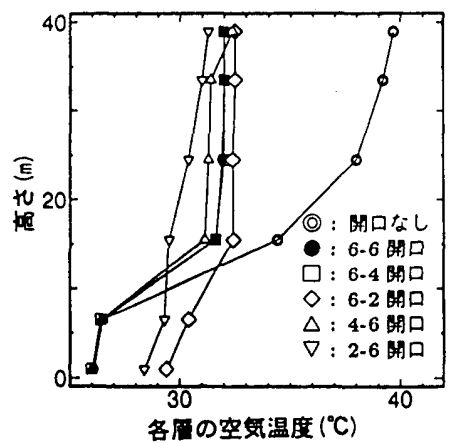

a）風上側、風下側開口高さが同じ場合

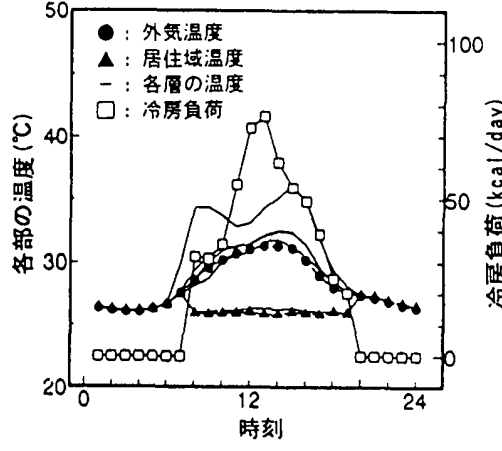

b）開口を設けた場合

図5 夏季における温熱環境の日変化

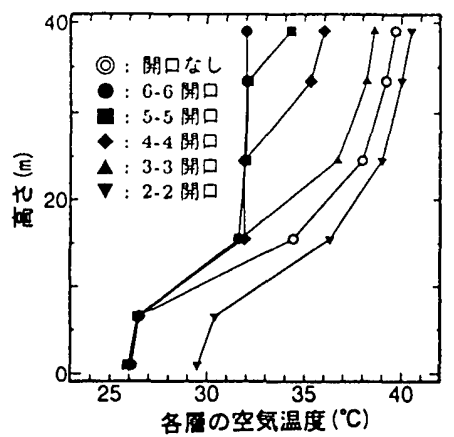

b）風上側，風下側開口高さが異なる場合

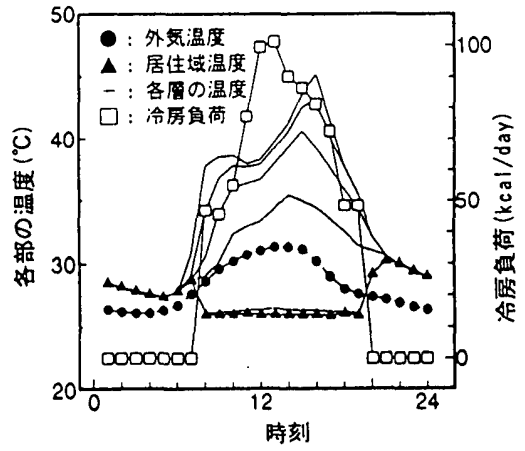

c) 開口のない䭪合

図6 開口設置高さによる屋内温度分布の違い

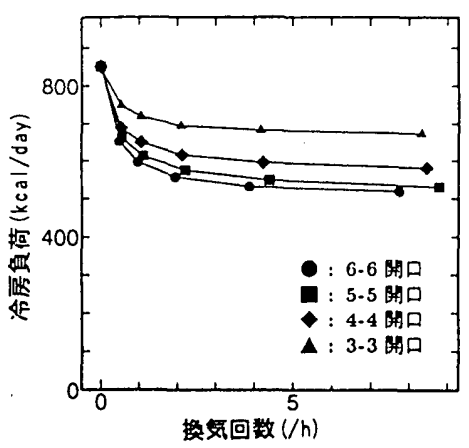

図7 換気回数による冷房負荷の違い

場合，図 6b) は風上側，風下側開口設置高さが異なる場合について 13 時における垂直温度分布を比較した結果である。2-2 開口条件以外の場 合には，開口部よりも上層側での温度が開口の設置により低減されてお り，熱だまりを除去する効果が得られている。なお 2-2 開口の場合に第 1 層, 第 2 層の温度が上昇しているのは，空調設定温度よりも高い温度 の外気が直接居住域に流入するためである。開口設定層の温度が外気温 度よりも高い場合には，外気の導入により熱だまりの除去効果が期待て きると考えられる。

各種条件について比較した結果，風上側，風下側の開口設置高さが異 なる場合には，より高い位置にある開口の影響が支配的となることがわ かった。図6b) はいずれか一方の開口を第 6 層とした場合であるが，開 口設埴位置が第 2 層以上にある 6-6，6-4 および 4-6 開口条件の場合に は垂直温度分布がほぼ一致している。いずれか一方の開口設置高さを第 5 層, 第 4 層として比較した場合にも同様の傾向が認められた。

\section{4 換気回数による冷房負荷削減効果の连い}

開口を設けた場合の冷房負荷削诚効果は外気風速によっても変化する 之考えられる。図 7 は風速条件を変化させた場合の冷房目荷を換気回数 で整理した結果である。各条件での冷房負荷の特性は開口の設置高さに よって異なるが，いずれの場合も換気回数の增加に伴い単調に減少して おり，換気回数 $2 \sim 3$ 回/ $h$ を越えるとほぼ一定值となることがわかっ た。外部風速がある程度以上の場合には開口の設置による負荷の低減が 十分見込めると考えられる。

\section{4. 外気導入による熱負荷削減効果に関する考察}

3 章までの検討により，アトリウムに開口を設置して外気を導入する と冷房目荷の削減が可能となることが確認できた。ここでは年間を通じ
てどの時期にどの程度の空調負荷の削堿効果が得られるのか，また気象 条件に合わせて開口の開閉操作を行うとすればどのような制御を行えば よいのかを考察した。

\section{1 空調負荷特性の通年変化}

3 章と同様のアトリウムを対象として外気導入のある場合，ない場合 についての空調負荷の通年変化を比較した。ここでは東京に立地するア トリウムを想定し，第 1 層での設定温度を年間を通じて $24{ }^{\circ} \mathrm{C}$, 空調時 間帯を 8 時〜 19 時として計算を行った。空調制御方式には CAV 制御 を想定し，期間熱目荷から求めた必要空調容量 21 )を空調機の最大空調 容量として表 5 のように設定した。なお外気を導入した場合には開口設 置位置を5-5 開口とし，常時開放したままとした。

空調目荷の通年変化に関する計算結果を図 8 に示す。外気を導入した 場合には夏季の冷房負荷を削減できるが，中間期から冬季までの期間で は当然ながら暧房負荷が大幅に増大する。空調負荷の問題のみに限定す れば無条件に開口を開放できるのは7月，8月の限られた期間であるが， $4 \sim 6$ 月および 9 月についても条件によっては空調負荷の削減は可能で あり，暖房負荷とのかねあいを考慮して外気導入を行えば十分に空調消 費エネルギーを削堿できるむのと考えられる。

\section{2 開口の開閉操作条件に関する検討}

図 8 に示した計算結果をもとに，外気導入による空調目荷削減が可能 な条件を検討した。ここでは 4 月から 10 月までの期間についての計算 結果を用いて気象条件と冷房負荷，暧房負荷との関係を比較した。

[外気温度および日射量と空調負荷との関係]

空調目荷の特性が外気温度に対して強い相関を示すことは容易に予測 できるが，日射量に関しては天候による影響が大きいためそのままの形 でデタを集計すると明確な関係がつかみにくいと考えられる。ここで 


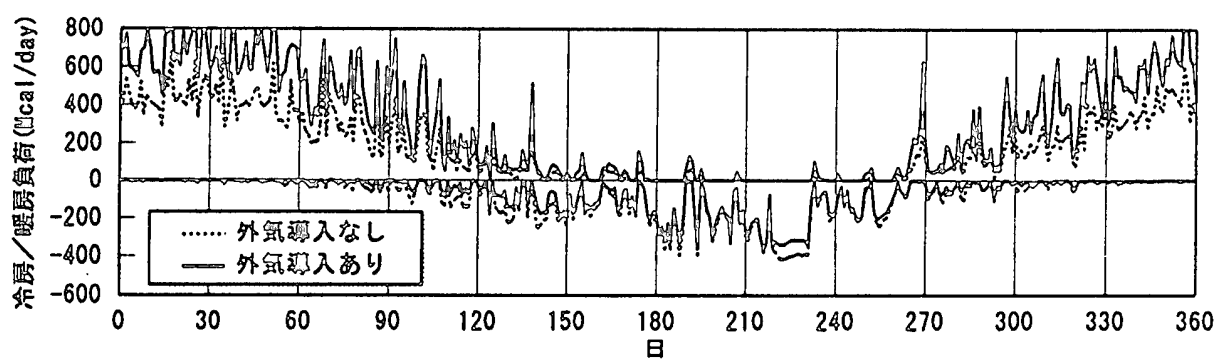

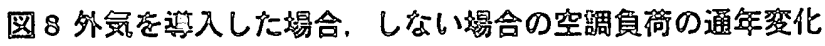

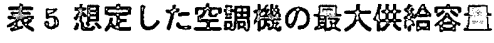

\begin{tabular}{|c|l|}
\hline 冷房時 & $420,000(\mathrm{kcal} / \mathrm{h})$ \\
\hline 暖房時 & $500,000(\mathrm{kcal} / \mathrm{h})$ \\
\hline
\end{tabular}

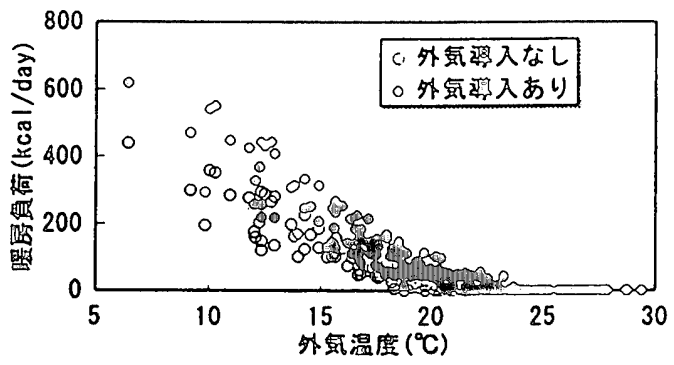

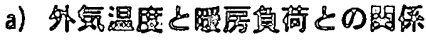

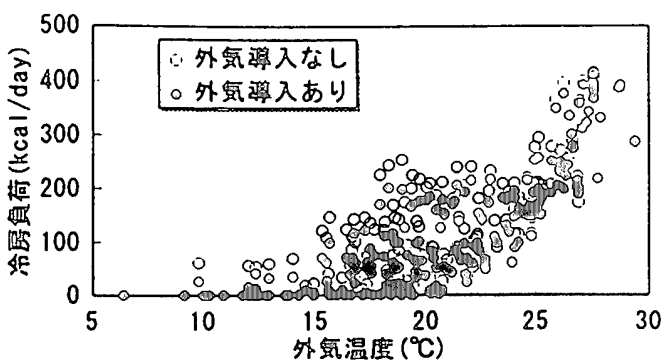

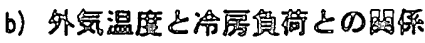

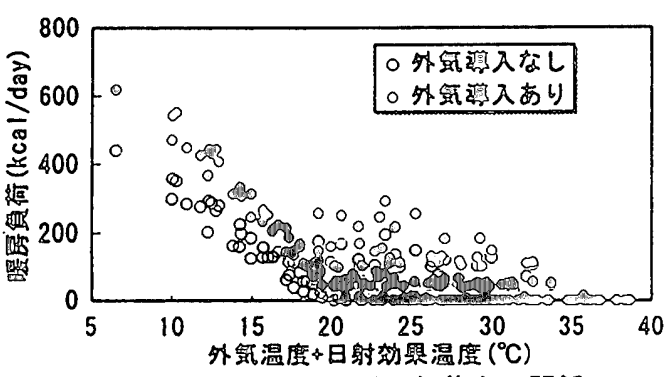

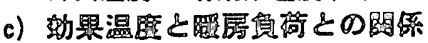

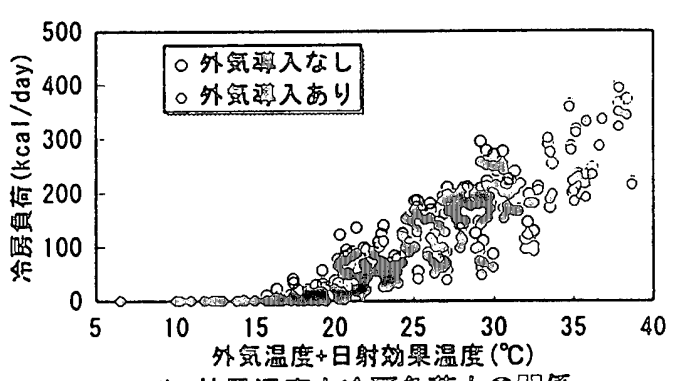

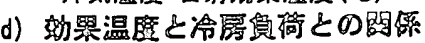

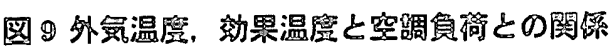

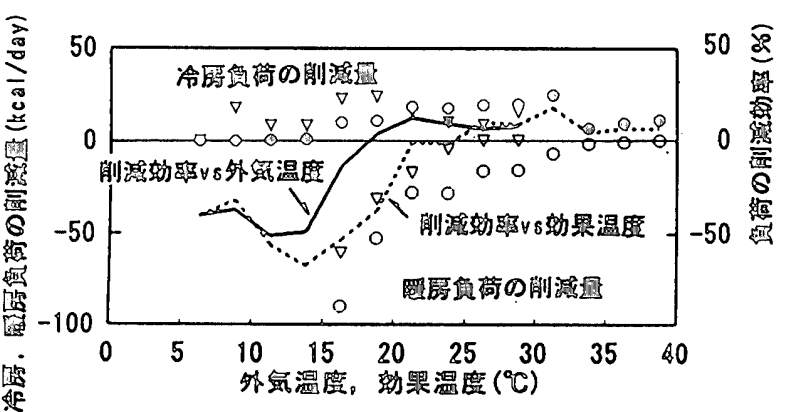

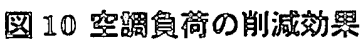

は拡張デグリデに用いられる考え方22)を応用し，対象建筑物外表面 への総合的な供給熱量として日射量を評価することとした。すなわち日 射による供給熱量を温度の単位に換算し，次の効果温度 $\theta$ を定篦する。

$$
\theta=T_{0}+\eta J / K, \quad \eta=\tau+A s \alpha_{i n} /\left(\alpha_{i n}+\alpha_{o u t}\right)
$$

図 9 は外気温度および (6) 式による効果温度をパラメータとして冷房 目荷，㖟房目荷との関係を整理した結果である。ただしここではデー夕 のばらつきを排除するため，各日の空調時間帯についての平均值を用い た。いずれの場合も空調目荷と外気温度, 効果温度との間には明確な閣 係が認められる。すなわち外気を導入した場合，しない場合の炆調目荷 は，外気温度や効果温度か特定の值となった時点を境にそれぞれ異なる 勾配の直線で近似できる。空調目荷が立ち上がるときの外気温度，勃果 温度にはいずれの場合も $3 \sim 5{ }^{\circ} \mathrm{C}$ 埤いがあり，この差の䈖团内におい て開口の開開操作を行えば空調目荷の削隇を可能とする制御が行えるす のと考えられる。

ただし中間期には冷房を必要とする条件之㖟房を必要とする条件とが 混在する。実際にはこの時期は冷房遇転，瞹房遣転のみ行うかまたは空 調を停止することになるから，冷房負荷の削诚のみに着目する之適切な 空調制御を行うことはできない。中間期については冷房，㖟房を含めた 総合的な空調消簤エネルギーの面から，外気を等入した場合，しない場 合のどちらが有利となるかを判断すること必要がある。ここでは冷房時 之暧房時の 2 次エネルギー側 COP の比率を用いて冷暧房目荷に重み付 けした值から空調目荷の削減勃率を考えることとした。图10はヒート ポンプを用いた場合を想定し、冷房時，㖟房時の COP の比を $2: 3$ 之仮 定 $^{23)}$ して园 9 の結果から評価した削減効率である。本研究で対象とし た建築物では，外気温度で $18^{\circ} \mathrm{C}$ 以上，効果温度で $24^{\circ} \mathrm{C}$ 以上の場合に宜 荷の削诚効率が正值を示しており，気象条件がの条件を満足した場合 に外気を導入すると，暧房負荷を增大させることなく冷房目荷を削減で きると教えられる。

[外氞風遗と空調負荷との閏係]

3.4 節の結果から，外気風嗃が大きいほど冷房目荷の削减勃果を得ら 


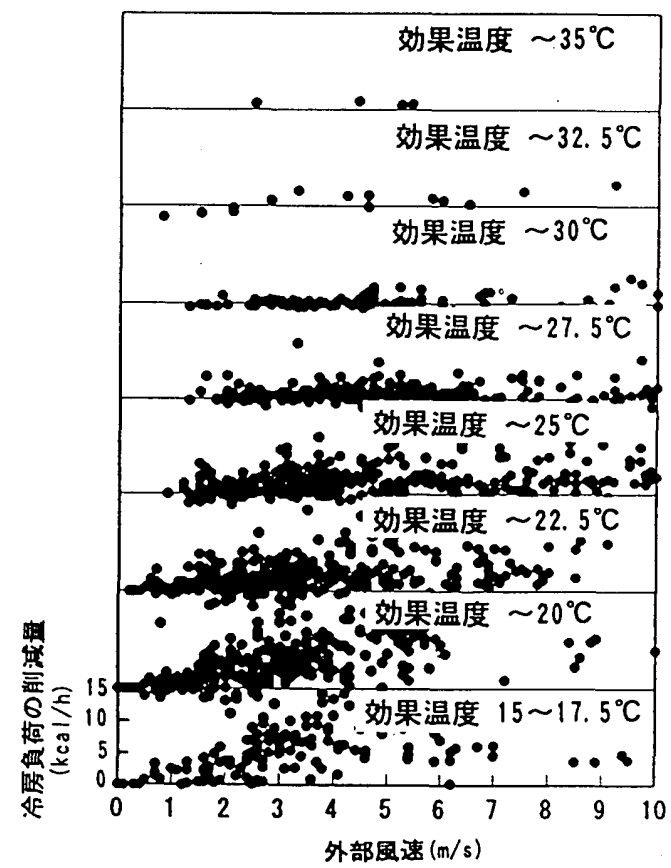

図 11 外気風速と冷房負荷削減勃果との関係

れることが示唆された。外部風速と冷房負荷削減量との関係について集 計した結果を図 11 に示す。外部風速は時刻ごとに大きく変化するため, ここではデータを 1 時間単位で集計し，(6) 式による効果温度ことに整 理した。特性にはかなりのばらつきがあるが，いずれの場合も風速に対 して冷房負荷の削減効果が増大する傾向が認められる。また効果温度が $30{ }^{\circ} \mathrm{C}$ 越えると外部風速が大きくても負荷の削減効果は頭打ちとなる ことがわかる。暧房負荷とのかねあいを考えると，効果温度 $25 \sim 30{ }^{\circ} \mathrm{C}$ の範囲で $2 \mathrm{~m} / \mathrm{s}$ 以上の風速がある場合には外気導入の効果が見込まれる と判断できる。

\section{3 開口の開閉制御による熱負荷削減効果}

[開口の開閉操作条件の設定]

外部気象条件に合わせて開口を開閉制御した場合の空調目荷を予測し た。ここでは東京，大阪，札棍，福岡の 4 地域を想定し，それぞれの地 域について 4.2 節と同粎の検討を行った結果から表 6 のような開閉操作 条件を設定した。なおここでは以下に示すような 4 種類の制御方法を想 定し，それぞれについて同侎の計算を行った。

•CASE-1：外気を導入せず，空調設定温度を $24{ }^{\circ} \mathrm{C}$ 一定とした場合 •CASE-2: 外気を導入せず，空調設定温度を一日単位で可変とした場合 -CASE-3: 外気を学入せず，空調設定温度を時間単位で可変とした場合 -CASE-4: 表 6 に従い開口の開閣操作により外気を導入した場合

CASE-2 は, 空調設定温度 $22{ }^{\circ} \mathrm{C}, 24^{\circ} \mathrm{C}, 26{ }^{\circ} \mathrm{C}$ の 3 とおりについて各日の 計算を行い，空調消費エネルギーが最む小さくなる条件をその日の空調 条件として採用したもの，CASE-3 は同様の操作を時間ごとに行ったも のである。実際にはこのような制御は不可能であるが，ここでは外気導 入を行わずに理想的な空調制御を行った場合の比較用データとしてこれ らの CASEを想定した。

[月ことよおよび年間の空調負荷削減効果]

年間にわたっての計算結果を月ごとに集計し，期間空調負荷の削堿量 の推移を考察した。各 CASEにおける期間空調負荷から CASE-1 の期 間負荷を差し引いた值を負荷削減量とし定義し，集計した結果を図 12
表 6 想定した開口開放条件

\begin{tabular}{|c|c|c|}
\hline 建設地 & 外気温度 & 日射相等温度 \\
\hline \hline 東京 & $20^{\circ} \mathrm{C}$ 以上 & $25^{\circ} \mathrm{C}$ 以上 \\
\hline 大阪 & $20^{\circ} \mathrm{C}$ 以上 & $25^{\circ} \mathrm{C}$ 以上 \\
\hline 札幌 & $24^{\circ} \mathrm{C}$ 以上 & $30^{\circ} \mathrm{C}$ 以上 \\
\hline 福岡 & $18^{\circ} \mathrm{C}$ 以上 & $25^{\circ} \mathrm{C}$ 以上 \\
\hline
\end{tabular}
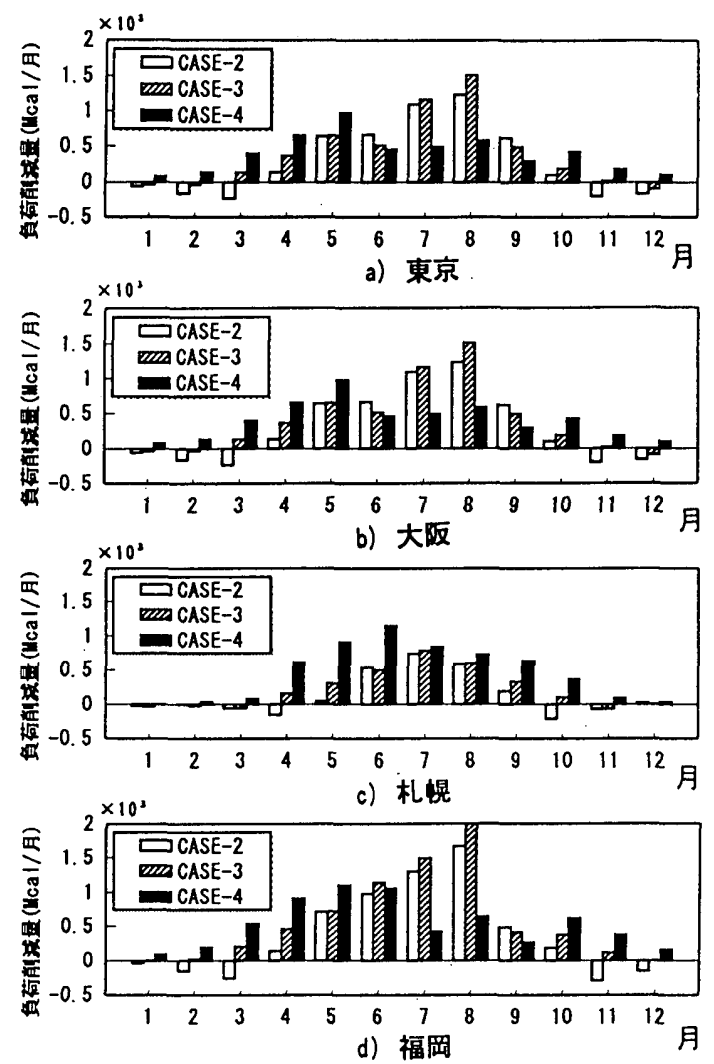

図 12 月ごとの空調負荷削減量

に示す。CASE-2，CASE-3では 7 月，8月の負荷削堿量が大きくなる のに対し，CASE-4では夏季から中間期までの長期にわたる効果が期 待できる。特に $3 \sim 5$ 月および 10 月，11 月において，いずれの地域 でもCASE-4 による効果がCASE-2，CASE-3 よりも大きくなってお り，開口の開閉操作による巽択的な外気導入は中間期における空調目荷 削隇に有効なことがわかっだ。

なお机幌では冷房が必要となる期間が短いか，この時期における空調 目荷削減量は他の地域に比へて数割程度大きくなることがわかっだ。外 気学入による温度制御は外気温度が空調制御温度に近い場合に最も効率 的であると考えられる。寒冷地では夏季から中間期までの比較的長期に わたって外気温度がそのようなレべルにあるため，本方式の適用が最も 有利となるものと考えられる。年間空調目荷の削減率を地域別に集計し た結果でも札幌での空調目荷削減率が最も大きな值を示した。

\section{5. 結 言}

開口部を有するアトリウムを対象として，自然換気により外気を導入 した場合の屋内温熱環境亡空調負荷特性を検討した。本研究では屋内垂 直温度分布と開口部からの外気流入の影響とを考虑した温熱環境予測モ 
テルを開発し，外気を導入した場合の屋内温熱環境の特性と消贯エネル キーの削減に効果的と思われる開口の開開制御方法などを考察した。こ こでは空調制御対象として顕熱のみをあつかったが，潜熱制御を考虑す

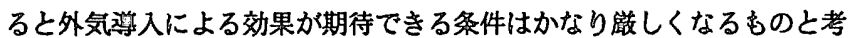
えられる。今後空調システムの墥いや潜熱の影㗽などについて検討を進 め, より詳細な考察を行っていく予定である。

\begin{tabular}{|c|c|c|c|}
\hline \multicolumn{4}{|l|}{ [㖐号] } \\
\hline$A$ & : & 開口面䅡 & $\left(m^{2}\right)$ \\
\hline$A_{f}$ & $:$ & 床面䅐 & $\left(m^{2}\right)$ \\
\hline As & : & 日射吸収率 & \\
\hline$A w_{n}$ & $:$ & $n$ 壁の面皘 & $\left(m^{2}\right)$ \\
\hline $\mathbb{B}_{i j}$ & $:$ & $i j$ 面間の Gebhart の吸収係数 & \\
\hline$C b_{j i}$ & $:$ & ij層間の乱流熱移動の係敏 & $\left(W / m^{2} K\right)$ \\
\hline$C p r$ & : & 空気の容積比熱 & $\left(J / m^{3} K\right)$ \\
\hline$g$ & : & 重力加速度 & $\left(\mathrm{m} / \mathrm{s}^{2}\right)$ \\
\hline$h_{p}$ & : & 壁面から降接セル中心までの距離 & $(m)$ \\
\hline$\dot{H}_{j}$ & $:$ & $j$ 層の内部発熱 & $(W)$ \\
\hline$H_{X E T}^{A C}$ & $:$ & 空調涗流から供給される熱量 & $(W)$ \\
\hline$H_{J E T}^{X}$ & $:$ & 外気流入に上り供給される熱量 & $(W)$ \\
\hline$J$ & : & 日射量 & $\left(W / m^{2}\right)$ \\
\hline$k$ & : & 乱流エネルギー & $\left(m^{2} / s^{2}\right)$ \\
\hline$K$ & : & 熟貫流率 & $\left(W / m^{2} K\right)$ \\
\hline$M_{j}$ & : & $j$ 層の空間熱容量 & $(W)$ \\
\hline$N$ & : & 開口の総数 & \\
\hline$N b$ & : & 層の分割數 & \\
\hline$N k$ & : & 壁面の総数 & \\
\hline$Q_{0}$ & : & 外気流入量 & $\left(m^{3} / s\right)$ \\
\hline$Q_{J E T}^{A C}$ & : & 空調吹き出し流唓 & $\left(m^{3} / s\right)$ \\
\hline$Q_{X O U T}^{A C}$ & $:$ & 空調噴流による誘引圄 & $\left(m^{3} / s\right)$ \\
\hline$Q_{X O U T}^{X}$ & $:$ & 外気流入に伴う訡引量 & $\left(m^{3} / s\right)$ \\
\hline$Q_{O U T}^{N}$ & $:$ & 開口からの流出流量 & $\left(m^{3} / s\right)$ \\
\hline$Q_{R E T}^{A C^{1}}$ & $:$ & 空調レターン吸い込み流量 & $\left(m^{3} / s\right)$ \\
\hline$Q r_{j i}$ & $:$ & $i$ 層から j層に流入する流量 & $\left(m^{3} / s\right)$ \\
\hline$Q w_{i n_{j i}}$ & $:$ & $i$ 壁側から $j$ 層に流入する壁面流 & $\left(m^{3} / s\right)$ \\
\hline$Q w_{\text {out }_{j i}}$ & $:$ & $j$ 層から $i$ 壁側で流出する壁面流 & $\left(m^{3} / s\right)$ \\
\hline$r_{i j n}$ & $:$ & $n$ 壁側の $i j$ 層間熱取得配分係数 & \\
\hline $\operatorname{sgn}[\mathrm{]}$ & : & [ ] ]内符昂をとる演算子 & \\
\hline$T_{0}$ & : & 外気温度 & $(K)$ \\
\hline & : & j層空気温度 & $(K)$ \\
\hline$T_{J E T}^{M A X}$ & $:$ & 最大供給容量での吹き出し温度 & $(K)$ \\
\hline$T_{m}$ & $:$ & 300 & $(K)$ \\
\hline$T s_{n}$ & . & $n$ 壁の内壁表面温度 & $(K)$ \\
\hline$T_{S E T}$ & : & 空調設定温度 & (K) \\
\hline$T^{\prime}$ & : & 䑝室 (地下) 温度 & $(K)$ \\
\hline$T_{J E T}^{\prime}$ & $:$ & 修正後の吹き出し温度 & $(K)$ \\
\hline$u_{1} \sim u_{3}$ & $:$ & 各座標方向の速度成分 & $(\mathrm{m} / \mathrm{s})$ \\
\hline$x_{1} \sim x_{3}$ & : & 各方向の座標 & $(m)$ \\
\hline$\alpha$ & : & 流量係数 & \\
\hline$\alpha c$ & : & 対流熱伝達率 & $\left(W / m^{2} K\right)$ \\
\hline$\alpha_{i n}$ & : & 内壁側総合熱伝達率 & $\left(W / m^{2} K\right)$ \\
\hline$\alpha_{\text {out }}$ & : & 外壁側総合熱伝遠率 & $\left(W / m^{2} K\right)$ \\
\hline$\alpha r$ & : & 放射熱伝達率 & $\left(W / m^{2} K\right)$ \\
\hline$\Delta P$ & : & 開口前後の圧力差 & $(P a)$ \\
\hline$\gamma$ & $:$ & 空気の比重 & $\left(N / m^{3}\right)$ \\
\hline$\varepsilon$ & : & $k$ の散逸率 & $\left(m^{2} / s^{3}\right)$ \\
\hline$\varepsilon_{r}$ & : & 放射係数 & \\
\hline$\rho$ & : & 空気の密度 & $\left(\mathrm{kg} / \mathrm{m}^{3}\right)$ \\
\hline$\sigma$ & : & Stefan-Boltzmann 定敏 & $\left(W /\left(m^{2} K^{4}\right)\right)$ \\
\hline$\tau$ & : & 日射䢪過率 & \\
\hline$\tau_{W}$ & : & 壁面剪断応力 & $(\mathrm{Pa})$ \\
\hline
\end{tabular}

[注]

[注 1] 従来の手法でも外気流入の影響はすきま風的な扱いで考虑されて いるか，外部気流状態によりその特性が大きく変化する自然換気 流の影餐は，これまでの手法では考珁されていない。

[注 2] 着目する壁面の内表面温度とこれに唹接する層およびその上下層 温度を比較して場合分けすると，壁面近傍で上昇流，下降流を生し た場合の壁面流温度と壁面流-隣接層間での流星収支が算出でき
ろ。下降流の場合には上層からの流れが，また上昇流の場合には下 層からの流れが混合するため，それそれの場合にあわせ上層また は下層側から順次場合分けの操作を行うことで内壁表面での対流 熱伝達と壁面流による層間熱移動量が計算できる。戸河里ら8),10) のモデでは同様の操作により熱取得配分係效 $r_{i j n}$ を計算してお き，層間熱移動の平衡式に壁面流の効果を表現している。

[注 3] 石田ら11),12)が用いた非等温噴流モテルの経験式は以下に示すと 晾である。すなわち

$$
\begin{aligned}
y=x \tan \alpha+ & A r\left\{\frac{x}{D_{0} \cos \alpha}\right\}^{2} D_{0} \\
\times & \left\{0.51 C_{S}\left(\frac{x}{D_{0} \cos \alpha}\right)+0.11\right\}
\end{aligned}
$$

ここに $A r$ :Archimedes 敏, $D_{0}$ : 吹き出し口相当径, $C_{S}$ : 展開係数 であり，噴流が水平方向に距離 $x$ 進行したとき，その中心軸が鉛 直方向に距離 yだけずれることを示している。噴流軌道から噴流到 達層を判别し，また噴流が通過した層界面での断面方向の風速プ ロファイルから誘引風量のフラックスを計算することができる。

[注 4] 空間内において着目するひとつの面要素が放射する熱量は，その面 が他のすへての面から吸収する熱量の総和に等しい。したかっってそ れそれの面要素から他の各面に配分され，実質的に吸収される放射 熱の割合を求めておけば, 壁間の相互故射による熱量授受が計算で きる。Gebhart の吸収係数は完全拡散面を仮定した場合の放射熱 分配の割合を示すものである。本研究で対象とした空問を楎成す る各層壁面および床面, 天井面の各面要素間での形態係数は比較 的容易に求まるので, 形態係数の相反則と壁面温度を常温之仮定 した線形化を用いることにより(3) 式の左辺第 4 項が学出できる。

[注 5] 建筑物を管成するすへての面が日射を透過するものと仮定すると， 着目する面が受照する領域はいくつかの異なる面を䢪過した日射投 影面から構成されていることとなる。このときの各投影面の面積比 はその時刻における太陽位置と建築物の方位とを考后して幾何学 的に求められる。着目する面での日射受熱量は各面での入射角度之 遥過率を考留して投影面皘比で重み付けして計算することとした。

[注 6] 本研究では外壁表面における対流熱伝達率を外壁に平行な風速成分 $v_{w}$ の関数として評価しており, 風向, 風速条件ことの $v_{w}$ をテー タバッファから参照して用いることとした。たたし対流熱伝達は各 層外壁面を単位として評価するので，実際にはデータバッファの風 這から算出した熱伝達率を面内で平均して用いている。

[注 7] ただし本研究では湿度に関する評価を行っていない。ここではいず れる影熱負荷についてのみ言及している。

\section{[参考文献]}

1) 日本建勧学会編:アトリウムの環境設計 (1994), 彰国社.

2) Chikamoto,T. et al: Proc.of ISRACVE(1992 Tokyo),26.

3) 宮川:空気調和衛生工学会諭文集,No.13(1990 6),1.

4) 宮川:空気調和衔生工学会論文集,No.13(1990 6),13.

5) 伊藤ほか:日本建築学会計画系論文報告集,398(1989 4),59.

6) Gautier,B. et al: Proc.of HBPSA(1991,Nice).

7) Bounia,H.: Modélisation simplifiée d'écoulements de convection mixte internes; application aux échanges thermo-aérauliques dans les locaux, Thése de Doctorat, Université de Poitiers(1993).

8) 戸河里ほか:日本建築学会計画系論文報告集,427(19919),9.

9) 戸河里ほか:日本建築学会計画系論文報告集,435(1992 9),11.

10) Togari,S. et al: ASHRAE Trans., 99 1(1993),84.

11) 石田, 宇田川:空気調和衛生工学会講演論文集 (1992 10),77.

12) 石田, 宇田川:空気調和衙生工学会講演論文集 $(199210), 81$.

13) Manzoni,D. and Rongére,F.X.: Proc.of 5th.Int.Conf.on ROOM VENT Vol.2(1996 Yokohama),443.

14) 諏訪ほか:日本建築学会計画系諭文報告集,486(1996 8).

15) 戸河里ほか:日本建築学会計画系諭文報告集,435(1992 5),11.

16) 絵内ほか:日本建築学会計画系諭文報告集, $419(1991$ 1),21.

17) Gebhart,B.: ASHRAE Trans., 65(1959).

18）近藤:空気調和衛生工学会シンポジウム,「大空間を中心とした最近 の熱目荷計算」盗料,(1993 3),46.

19) 日本建築学会酎風設計資料小委員会編:流体計算之風荷重評価 (1994 11).

20) 森川:日本建築学会大会学術梗概集, $\mathrm{D}(1989$ 10),455.

21) 空気調和衛生工学会編:空気調和設備計画, 設計の実務の知識 (1995), オーム社

22) 木村 繶:建築環境学 1 (1992, 第 3 版), 丸善.

23) 井上:空気調和ハンドブック (1991, 第 3 版), 丸善.

（1995年 9 月 26 日原稿受理，1996年 8 月 23 日操用決定） 